\title{
放射光を用いた薄膜評価とダイヤモンドライクカーボン膜の国際標準化*
}

\author{
神田一浩*1
}

\section{Evaluation of Thin Films by Using Synchrotron Radiation and International Standardization of Diamond-Like Carbon Thin Films Kazuhiro KANDA*1}

*1Laboratory of Advanced Science and Technology for Industry, University of Hyogo, 3-1-2, Koto, Kamigori, Ako, Hyogo 678-1205, Japan

(Received November 12, 2012, Accepted February 17, 2013)

\begin{abstract}
Synchrotron radiation, which has characteristics of high energy, high brilliance, high directionality, and high polarization, is a useful light source for the evaluation of thin film. International standardization project of diamond-like carbon (DLC) film is proceeding on the basis of the measurement of the near edge X-ray absorption fine structure (NEXAFS) spectroscopy using synchrotron radiation. NEXAFS has been utilized as a precise method of $s p^{2}$ content for DLC films. The $s p^{2}$ content can be extracted from the NEXAFS spectrum with a high sensitivity and a high quantitativity, because the isolated peak corresponding to carbon $1 s \rightarrow \pi^{*}$ resonance transition can be observed.
\end{abstract}

\section{1. はじめに}

ナノテクノロジーの進展に伴うダウンサイジングの進行 で, 薄膜の重要性・需要はとみに増加し,さらに薄膜の中で も超薄膜と呼ばれるような膜厚の薄い膜のニーズが増大して いる. 半導体や液晶パネルに代表される電子部品は, シリコ ンウェハやガラス基板上に配線や薄膜をつけて製造されてい るが，高集積化が進むに伴って膜厚は極限まで薄くなりつつ ある. また, 保護膜などでも構造の微細化により, 超薄膜化 が進んでいる. 例えばパターンドメディアやマイクロレンズ アレイで用いられているナノインプリントリソグラフィー (Nanoimprint Lithography, NIL) は, 安価に高速でナノメー トルパターン構造を転写できるが，すでに $30 \mathrm{~nm}$ line \& spaceのパターンを持つモールドの転写が実現している $(\text { Fig. 1 })^{1)}$ 。このモールドに着ける保護膜・離型膜は, 例え 膜厚 $5 \mathrm{~nm}$ でも 2 割の寸法䛊差を生じることになる．このよ うに, 産業界における薄膜の重要性が増すにしたがい, 薄膜 の評価・分析の重要度も増している．このような超薄膜・超 微量な対象を, 従来型の分析一例えばガククロマトグラフ ィーや固体 NMR-で測定しようとすると膨大な試料が必要 となる. それどころか，ビーム技術を用いたラザフォード後 方散乱分光法 (Rutherford Backscattering Spectrometry: RBS) や二次イオン質量分析計 (Secondary Ion-microprobe Mass Spectrometer: SIMS) ですら, 余りに早く膜を蒸散さ せてしまうために測定困難で, 評価・分析には分光的手法を 用いることが求められる.

このような微量高精度の分光分析の光源には, シンクロト ロン放射光 (Synchrotron Radiation: SR）が有効活用され ている. 放射光は光速近くに加速された荷電粒子が磁場など の中で進行方向を曲げられたときに接線方向に放出される電 磁波であり, 高輝度·連続性・高指向性・偏光性・清浄性な ど様々な利点を持っている. 特に通常のレーザーでは発振で

* 平成 24 年11月 14 日 第53回真空に関する連合講演会で発表

*1 兵庫県立大学高度産業科学技術研究所 ( 穂郡上郡町光都 3-1-2)

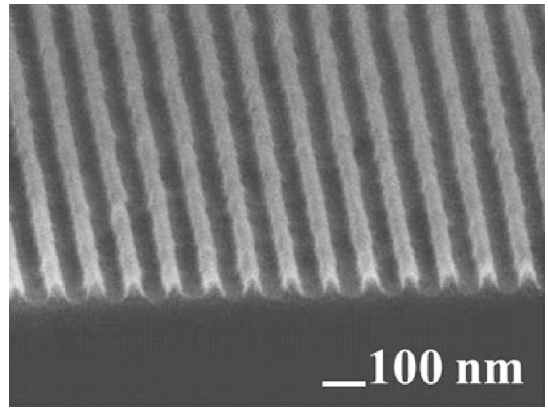

Fig. 1 SEM photograph of mold for Nanoimprint Lithography.

きない真空紫外領域, 軟 $\mathrm{X}$ 線領域, 硬 X 線領域など高エネ ルギー領域の連続光源としては, 唯一の存在である ${ }^{2)}$. 放射 光を用いた化学状態分析には X 線光電子分光法, $\mathrm{X}$ 線蛍光 分光法, $\mathrm{X}$ 線吸収分光法の 3 種が知られている.これらは いずれも内殼電子の励起を利用しており，特定の元素を標的 として測定が可能である. 特に X 線吸収分光法は，1）光電 子分光法のような超高真空を必要としない，2）X 線結晶回 折法と異なり，アモルファス構造でも評価可能，3）固体 . 表面・粉末など様々な試料形態で測定可能，4）ややエネル ギーの高い領域では, He 雾囲気置換により, 液相または湿 った試料でも測定可能，5）検出方法を選ぶことで, 絶縁体 や生体試料でも測定可能，6）検出方法を選ぶことで, 表層 からバルクの情報が取得可能，7）空準位の利用が可能 と 非常に多くの利点があり, 産業分析に多用されている33.

\section{2. 放射光施設之 $\mathrm{X}$ 線吸収分光分析}

物質，すなわち分子に含まれる電子は価電子と内殼電子に 2 分される. 価電子は原子間の結合に関与する電子であり, 複数の原子上に存在確率を分布して分子軌道を形成する. 複 数の分子軌道のエネルギーは重なって抢り，原理的に分離す ることは不可能である. 価電子のエネルギーは数 $\mathrm{eV}$ から 50 $\mathrm{eV}$ 程度であり, 紫外線から真空紫外線の領域に相当する. 内殼電子は結合に用いられない内殼の電子であり, 一つの原 
子上に局在する。したがって内殼電子のエネルギーは結合に 関係なく，元素によって固有でかつ離散的であるために，特 定の元素を選択的に分析できる利点がある.内殼電子のエネ ルギーは，例えば $K$ 殼のイオン化エネルギーはリチウムで は5 $54.7 \mathrm{eV}$, 酸素は5 $543.1 \mathrm{eV}$ と元素が重くなるにつれて増加 する. 第 3 周期以上になると $L$ 殼, 第 4 周期になると $M$ 殼 も内殼電子となり，測定することが可能になる．金では $M$ 殼は $2205 \mathrm{eV} ， L$ 殼は $11919 \mathrm{eV} ， K$ 殼は $80724 \mathrm{eV}$ にな る.リチウム, 炭素, 窒素, 酸素をたは, アルミニウム, シ リコンといった現在の産業で主役をなしている主要な元素が 含まれる第 2 第 3 周期の元素の内殼電子のエネルギーは数 十 $\mathrm{eV}$ から数 $\mathrm{keV}$ の軟 $\mathrm{X}$ 線領域と呼ばれる領域に相当す る. 軟 $X$ 線領域の連続光源としては放射光以外に存在しな いため, 放射光を用いた化学状態分析が実用的な産業分析と して利用されている.

$\mathrm{X}$ 線吸収分光分析を行うには放射光施設が必要となる. Fig. 2 は兵庫県立大学が有するニュースバル放射光施設で ある。ニュースバルは SPring-8サイト内に位置し, SPring-8の直線加速器から電子を供給されている。ニュースバ ルの蓄積リングは周長 $118 \mathrm{~m}$ の中型リングであり, 蓄積電子 のエネルギーは $1.0 \mathrm{GeV}$ または $1.5 \mathrm{GeV} て ゙$ 運転されている. ニュースバル蓄積の臨界光子エネルギーは $1.0 \mathrm{GeV}$ 運転時で $700 \mathrm{eV}$ であり，軟 $\mathrm{X}$ 線領域利用に特化された放射光施設で ある4).

放射光施設の電子蓄積リングから試料を測定する実験ス テーションまで放射光を導く装置をビームラインと呼ぶ. $\mathrm{X}$ 線吸収分光測定が可能なビームラインの例としてニュースバ ルビームライン05（BL05）に設置された産業用分析ビーム ラインをFig. 3 に示す. ビームラインには，排気装置·真 空バルブ・各種モニタ・安全装置などのほかに, 集光などの ためにミラーなどの光学素子が含まれる．軟 X 線領域では 空材すなわちレンズが使えないため, ミラーを用いた反射光 学系を使って実験ステーションに光を集光・導入する必要が ある．X 線吸収分光を測定するビームラインには，このほ かに放射光をエネルギー分解し, 掃引する分光器が必要であ る. ニュースバル BL05 は回折格子分光器を備え, 50〜 $1300 \mathrm{eV}$ の分光分析が可能な BL05B と二結晶分光器を備え, $1300 \sim 4000 \mathrm{eV}$ の分光分析が可能な BL05A の 2 本のブラン チラインで構成され，全体で $50 \sim 4000 \mathrm{eV}$ の範囲で分光分析 が可能である。これは $\mathrm{L}$ 殼の励起でスズ， $\mathrm{M}$ 殼励起ではビ

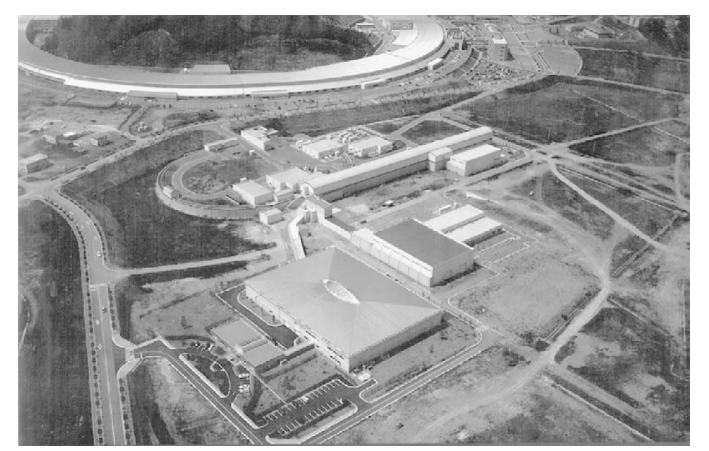

Fig. 2 Photograph of NewSUBARU synchrotron facility.
スマスまでの分光分析が可能であることになる.

このような分光ビームラインを用いて, 物質に当てる $\mathrm{X}$ 線のエネルギーを徐々に上げていくことを考えてみよう。原 子の内殼電子の結合エネルギーに相当するエネルギー以下で は，X線の吸収は起きないが，結合エネルギーを超えると 光イオン化過程が起きるために $\mathrm{X}$ 線の吸収係数が急激に上 昇する（Fig. 4).X 線吸収スペクトルにおけるこのエッジ 構造を吸収端と呼んでいる。吸収端よりも入射 X 線のエネ ルギーが大きくなると吸収係数は次第に減衰するが，吸収端 から $1000 \mathrm{eV}$ 程度の高エネルギー領域にかけて吸収係数に微 細構造（振動構造）が観測される。この微細構造をX線吸 収微細構造（X-ray Absorption Fine Structure: XAFS）と呼 んでいる.XAFS は非常に高感度で, 着目元素が極微量ま たは極低濃度（ppm オーダー）でも分析可能であり，超薄 膜の分析評価に適している.

$\mathrm{XAFS}$ は, 吸収端から $50 \mathrm{eV}$ 程度の領域に現れる吸収端近 傍 X 線吸収微細構造（NEXAFS: Near Edge X-ray Absorption Fine Structure: NEXAFS，または XANES: X-ray Absorption Near Edge Structure) と，それ以上のエネルギー で現れる広域 X 線吸収微細構造 (EXAFS: Extended X-ray Absorption Fine Structure）に分けられ（Fig. 4）これらは 構造の生成原理が異なっている. 高エネルギ一側で生じる EXAFS は, 励起電子と近接原子からの散乱電子の相互作用 に起因して得られる振動構造であり, フーリエ变換により得 られる動径分布関数は, 着目元素の局所構造（周囲の原子 種, 配位原子の数, 原子間距離) に関する情報を含んでい

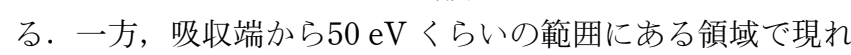

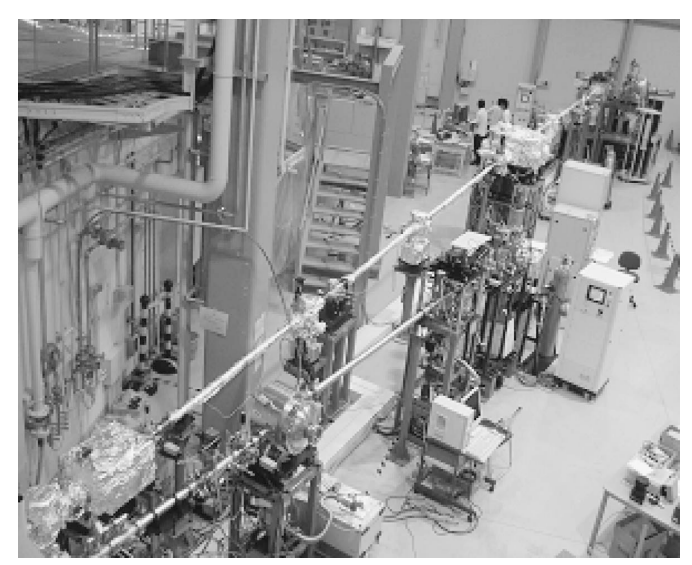

Fig. 3 Photograph of NewSUBARU beamline 05 .

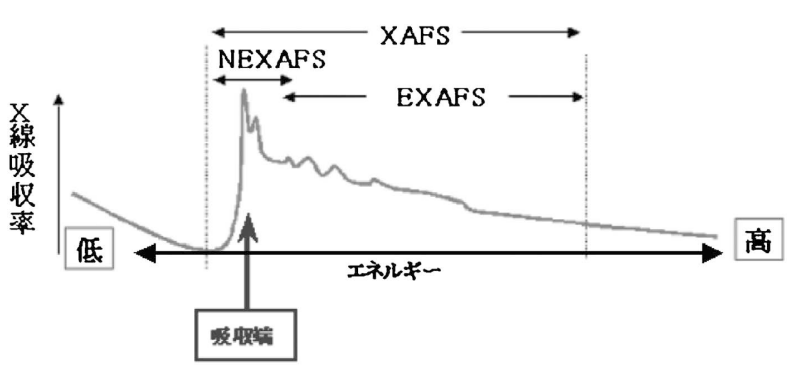

Fig. 4 X-ray absorption edge and X-ray absorption fine structure. 
る NEXAFS のピークは内殼電子が空軌道一非占有軌道一に遷 移するエネルギーに対応し, 着目元素の価数や配位構造等に 依存したスペクトル構造を取る.このように空軌道への励起 を観測できるのが NEXAFS の特徵であり, 後述するように 高い精度で DLC 膜の $s p^{3} /\left(s p^{2}+s p^{3}\right)$ 結合比を決定できる理 由である。

\section{3. ダイヤモンドライクカーボンの構造と NEX-} AFS スペクトル

ここ10年に渡ってナノテクノロジーの進歩が著しく, 様 々なナノ加工技術が確立されて多種多様のナノマイクロデバ イスが作製されている．このようなナノマイクロスケール構 造物の表面物性制御にはマクロスケールで用いられていた手 法・素材では限界があり，ナノテク素材と呼ばれる新しい素 材が注目されている.アモルファス状の炭素膜は高硬度や耐 磨耗性などダイヤモンドと似た性質を持つことからダイヤモ ンドライクカーボン (Diamond-Like Carbon: DLC) 膜と呼 称されており, 代表的なナノテク素材であり, その市場を拡 大させている.

DLC 膜はダイヤモンドやグラファイトと異なり, 定まっ た結晶構造を持たないアモルファス構造をとっている（Fig. 5). これを原子レベルの局所構造で考えると, ダイヤモン ドが $s p^{3}$ 混成軌道を持っている炭素原子のみで形成され, グ ラファイトが $s p^{2}$ 混成軌道を持っている炭素原子の久で形成 されるのに対し, DLC膜中ではダイヤモンド構造に対応す る $s p^{3}$ 混成軌道を持っている炭素原子とグラファイト構造に 対応する $s p^{2}$ 混成軌道を持っている炭素原子が混ざり合って いると考えられる.この膜中に存在する $s p^{3}$ 混成軌道を持っ ている炭素原子と $s p^{2}$ 混成軌道を持っている炭素原子の存在 比, $s p^{2} / s p^{3}$ 比は DLC 膜の硬度など様々な物性に密接な関係 を持つため, DLC膜のキャラクタリゼーションの重要なフ

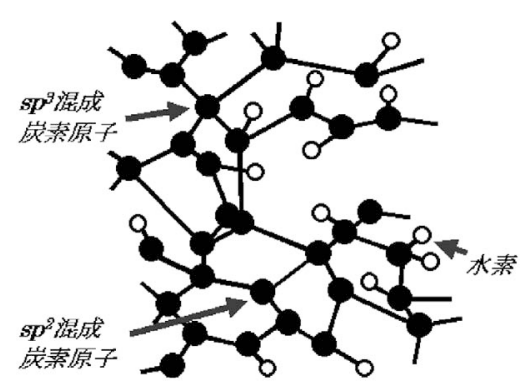

Fig. 5 Schematic diagram of DLC.

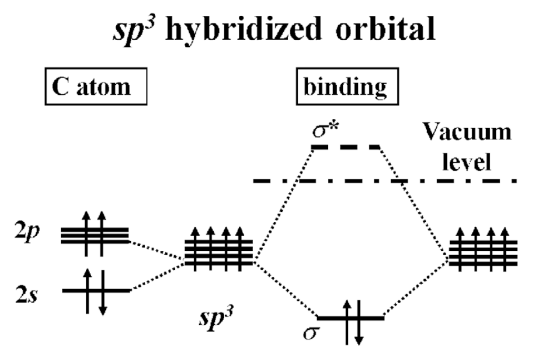

アクターである．また，ダイヤモンド，グラファイトは純粋 に炭素のみで形成されるが，DLC 膜は炭化水素を原料にす ることが多いため, 膜中に水素を含む場合が多い. 膜中の水 素の存在比もDLC 膜の電気伝導度などの基本物性に強い相 関を持っている重要なファクターである．このような背景を 基に炭素と水素からなるDLC 膜を分類する手段として $s p^{2}$ 比· $s p^{3}$ 比・水素存在比をトライアングルとする図が Jacob らによって提唱され ${ }^{5)}$, Robertson らにより水素化炭素膜の 3 元状態図にまとめられて流布している6).

$\mathrm{DLC}$ 膜中の $s p^{3} /\left(s p^{2}+s p^{3}\right)$ 結合比の決定にはこれまでレー ザーラマン分光法や光電子分光法, 電子エネルギー損失分光 法 (Electron Energy Loss Spectroscopy: EELS) など様々な 手法が用いられて来たが，十分な精度で結果を得るに至らな かった ${ }^{7)}$. 近年, DLC 膜中の $s p^{3} /\left(s p^{2}+s p^{3}\right)$ 結合比の決定 にNEXAFS が有効であることがわかってきた ${ }^{8-10)}$.

炭素原子は不対電子を 4 つ持っており, $s p \cdot s p^{2} \cdot s p^{3}$ とい う 3 種類の混成軌道を形成することが知られている. 固体 であるアモルファスカーボン膜の中では sp 混成軌道による 結合はエネルギーが高いために存在量は無視できるので, $s p^{2}$ 混成軌道を持つ炭素原子と $s p^{3}$ 混成軌道を持つ炭素原子 の存在比が DLC の構造因子となる. 炭素原子の電子軌道準 位を Fig. 6 に示す. 炭素原子は隣接する原子と電子を出し 合って結合を形成するが， $s p^{3}$ 混成軌道を取る場合には $\sigma$ 性 の軌道のみを形成する。 $\sigma$ 性の結合の空軌道は真空準位より 高い場所に存在する. 一方, $s p^{2}$ 混成軌道を取った場合には, 1 つ電子が余り, これが $\pi$ 結合を形成する. $\pi$ 結合の空軌道 は真空準位より下に位置し， $\sigma$ 結合の空軌道に比べると 10 $\mathrm{eV}$ 程度低い. $\sigma$ 性の軌道は $s p^{2}, s p^{3}$ 結合の双方に存在するた めに, $\sigma$ 性の空軌道も両者に存在し, この空軌道を経由する $1 s \rightarrow \sigma^{*}$ 遷移を引き起こす. 一方, $\pi$ 性の軌道は $s p^{2}$ 混成軌道 にしか存在しないため, $\pi$ 性の空軌道を経由する $1 s \rightarrow \pi^{*}$ 遷 移は $s p^{2}$ 混成軌道を作っている炭素原子でしか起こらない. したがって， $1 s \rightarrow \pi *$ 遷移を分離検出することで, DLC 内の $s p^{2}$ 混成原子の存在比を知ることができる.

Fig. 7 に一般的な DLC 薄膜の炭素原子 $K$ 端 NEXAFS ス ペクトルを示す。炭素のイオン化エネルギーは $295 \mathrm{eV}$ であ るので, このエネルギーより高いエネルギーでは直接光イオ ン化で生じた光電子が含まれる. Fig. 7 の Direct ionization と示した部分には光電子とその後続反応である正常オージェ 電子，およびそれらに起因して放出される 2 次電子が含ま れる. Fig. 6 に示したように炭素原子では $\sigma$ 性の空軌道が イオン化エネルギーより高エネルギー側に, $\pi$ 性の空軌道は

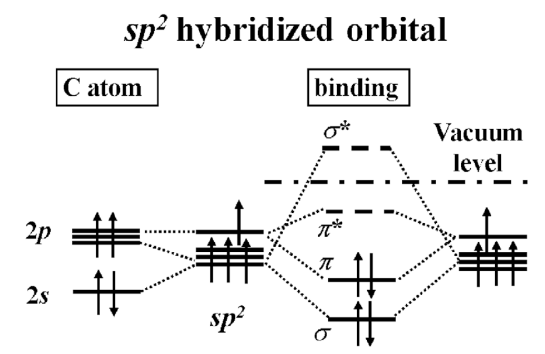

Fig. 6 Electron energy of carbon atom in DLC. 


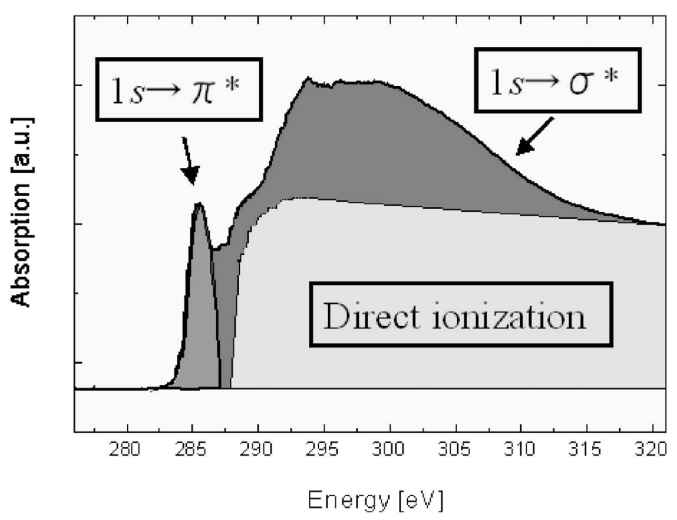

Fig. 7 NEXAFS spectrum of DLC.

イオン化エネルギーより低エネルギー側に存在するという特 徵を持っている. 290〜 $310 \mathrm{eV}$ に存在するブロードなピーク は C $1 s \rightarrow \sigma^{*}$ 共鳴オージェ電子放出過程に由来するオージェ 電子およびそれに起因して放出される 2 次電子を反映して いる．グラファイト，ダイヤモンドのような結晶性の物質で は $1 s \rightarrow \sigma^{*}$ 遷移はシャープな構造を与えるが，DLCはアモ ルファス構造であり， C-C 結合が様々な核間距離を持つな ぞ炭素原子が様々な化学環境に存在するために, $1 s \rightarrow \sigma^{*}$ 遷 移に対応するピークもこのようにブロードになる. $285.4 \mathrm{eV}$ 付近に観測されるピークは $1 s \rightarrow \pi^{*}$ 共鳴オージェ電子放出過 程に由来するオージェ電子拈よびそれに起因して放出される 2 次電子を反映している。 $\sigma$ 性の軌道が結合軸上に電子分布 を持つのに対し， $\pi$ 性の軌道では結合軸が節になって電子分 布を持たないために， $\pi$ 軌道のエネルギーは核間距離に鈍感 でほとんど広がりが起きず，鋭いピークとなって分離して観 測される．このように大きな空軌道のエネルギー差を利用で きることと， $\pi$ 性の遷移は鋭いピークとなることが，NEX$\mathrm{AFS}$ 測定法の特長であり, $1 s \rightarrow \pi *$ 遷移を分離して観測する ことで, $s p^{3} /\left(s p^{2}+s p^{3}\right)$ 結合比を高い精度で決定できる. 実 際には定めた領域の吸収強度の積分值 $\left(I_{\text {all }}\right)$ と $1 s \rightarrow \pi^{*}$ のピー ク面積 $\left(I_{\pi}^{*}\right)$ の比 $\left(I_{\pi}^{*} / I_{\text {all }}\right)$ を算出し,$s p^{2}$ 組成が $100 \%$ で ある HOPG $の I_{\pi}^{*} / I_{\text {all }}$ と比較して $s p^{2} /\left(s p^{2}+s p^{3}\right)$ 結合比を決 定する. 詳細な測定方法・解析方法については文献10)を参 照されたい。

\section{DLC 膜の国際標準化プロジェクト}

DLC 膜は以前からドリルなどの切削工具などのコーティ ングに用いられて来たが, 高硬度・耐摩耗性に加えて, 低摩 擦係数や耐食性・ガスバリア性などに着目され，ナノマイク ロパーツのコーティング材料としてナノテク産業分野で利用 が拡大している．その代表的な利用分野としてはコンピュー タハードディスクやヘッドが挙げられ，10 nm 程度の膜厚な がら磁性膜の保護の役割を果たしており，機械的衝撃などの 危機から膨大な情報を守っている．そのほかにも太陽光発電 電池 ·湯水混合栓・人工血管やカテーテルなど生体インプラ ント部品, ナノインプリントリソグラフィー用のモールド, さらにはペットボトル・味増容器などの食品容器へのコーテ ィングに用いられている. 中でも注目されるのは自動車の工 ンジンに用いられるバルブリフターへのコーティングであり,
DLC 膜の利用により然費が 4\%改善されると見込まれてい る. DLC 膜はこのように低摩擦係数・耐磨耗性に優れてい るために摺動部品のコーティングによるエネルギー変換効率 の上昇・耐磨耗による部品寿命の超寿命化などにより省エネ ルギー・ $\mathrm{CO}_{2}$ の削減にも大きく寄与できると期待されてい る. DLC の市場規模は2011年には63億円程度であったが， 前年比 $10 \%$ の規模で増加しており，2015年には93億円に達 する見込みとなっている11).

このように多岐に渡る先端応用分野で DLC 膜が活用され る一方で, DLC膜の物性を一義的に決めることができない という問題が顕在化してきた. DLC 膜は数多くの有用な特 性を持つため, ひとつの手法を用いて特定の条件で作製した DLC 膜がすべての有用な特性をもつのではなく，様々な製 造手法が用いられて様々な DLC 膜が生産されているにもか かわらず，「DLC」という名称でひとくくりにしていること の矛盾が製品紹介や知的財産権習得などの面で現実的な問題 となっている，例えば特許で「DLC」と記載しても，構造· 組成の定義が明確でないため, 権利が弱く諸外国から侵害の 危険性を排除できないなどの懸念が強まっている.

この懸念を解決するためには「に゙こまでが DLC 膜なの か」，「どのような DLC 膜が存在するか」，「どのような用途 にはどの DLC 膜が適しているか」など系統的な知見を得る ことが必要であり，そのためには，DLC膜のさまざまな構 造や物性を定量化し，分類する必要がある。DLC膜はわが 国がシェアの $40 \%$ を占める世界をリードする素材であり, 次の10年にも日本が世界市場において DLC 膜を稼ぎ頭とし て維持するためには先導をとって DLC 膜の標準化を行う必 要がある。この目標を達成するために, DLC膜の構造・物 性・製膜法の関係をあきらかにするDLC 研究会によるDLC 標準化プロジェクトが進行している.

DLC 研究会は平成 16 年度日本学術振興会基盤研究 C（企 画調查)「アモルファス炭素系薄膜の科学」で発足した．こ の企画調查に拈いてプロトタイプの試料收集・測定を行い, DLC 膜の素性を科学的に明らかにするための方針（POLICY2004）を策定した．POLICY2004では「合成班の提供す る試料を構造班・特性班・性能班の複数の設備で評価する組 織的科学手法を模索する」ことを求めている. DLC 膜の構 造評価に関して様々な分析法を検討した結果, $s p^{2} / s p^{3}$ 比の 決定に吸収端近傍 X 線吸収微細構造法 (NEXAFS), 水素 組成の決定に弾性反跳分析法（Elastic recoil detection analysis：ERDA）が採用された。平成17年度には POLICY2004 をもとにした行動計画が PLAN2005として提案され, さら にそれまでの成果を600ページに拈よぶ集大成「DLC 膜ハン ドブック」にまとめ，公表を行った ${ }^{12)}$ 。平成18年度には PLAN2005がACTION2006として本格的に実施された。 ACTION2006の目的は, 平成22年までにDLCを科学的に定 義する GUIDELINES2010を策定することであった．この実 現のためにNEDO 公募プロジェクト「DLCの特性とその測 定・評価技術の標準化に関する調査」において企業 14 社, 公的試験機関など 5 箇所, 大学 12 校で参加し, 58 種類の DLC 膜について, ラマン分光 · 接触角 · 光学特性 · 細胞親 和性試験などおよそ 20 項目の評価を行うラウンドロビンテ 
ストを行った. 本テストによって得られたデータベースは評 価対象の多さ・検査項目の豊富さから DLC 膜に関して国際 的に見ても最大の情報量を有している7).

この受託研究の成果を元にDLC 膜の国際標準化を日本で 行うことの重要性を経済産業省に働きかけ，平成 21 年度よ り国際標準共同研究開発事業「ダイヤモンドライクカーボン 膜及び評価方法に関する標準化」が開始された．この事業は ダイヤモンドライクカーボン (DLC) 膜の分類とその評価 技術に関する国際規格を制定することを目的とし，具体的に は ISO/TC107（金属及び無機質被膜）などでの規格制定を 目指して活動を行った. 平成 23 年度に一度終了したが, ISO 取得の可能性が高いと判断されて今年度からさらに 3 年間 の継続事業として認められ, 平成 25 年度に ISO 提案を行う ベくプロジェクトを進めている. Fig. 8· Table 1に ISO に 提案するDLC 膜の分類案を示す.

- TYPE I は $s p^{3}$ 成分が多く, 水素の少ない高硬度の tetrahedral amorphous carbonであり，製造法から見ると PVD 法にほぼ限定される。密度は打打よそ $2.6 \mathrm{~g} / \mathrm{cm}^{3}$ 以上, 硬度 おおよそ50 GPa 以上の膜である.

- TYPE II は $s p^{3}$ 成分が多く, 水素の多い低硬度の hydrocarbon polymer に近い DLC 膜である. アルミ缶加工 工具, 医療機器など溶着防止や耐食性の必要な部位に用いら

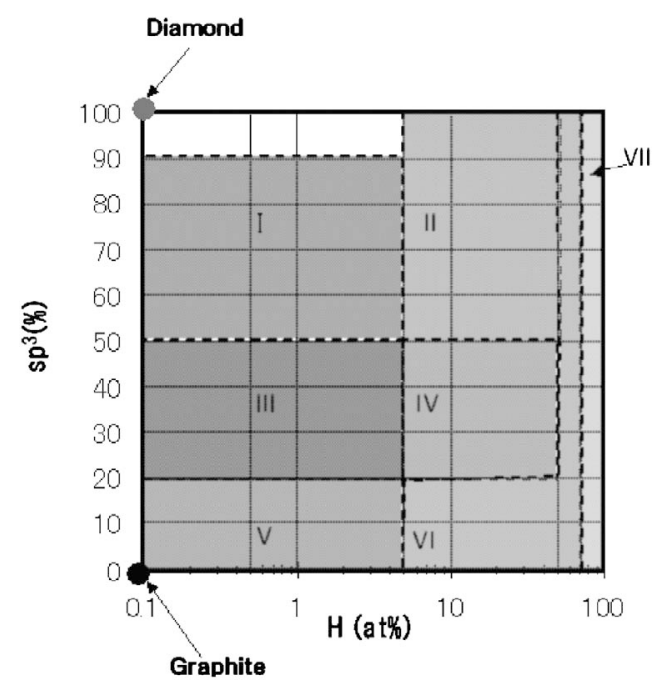

Fig. 8 Classification plan of DLC films.

Table 1 Classification plan of DLC films.

\begin{tabular}{c|c}
\hline \hline TYPE & 名 称 \\
\hline I & ta-C \\
\hline II & ta-C $: \mathrm{H}$ \\
\hline III & $\mathrm{a}-\mathrm{C}$ \\
\hline IV & $\mathrm{a}-\mathrm{C}: \mathrm{H}$ \\
\hline V & GLC \\
\hline VI & PLC \\
\hline VII & 膜なし
\end{tabular}

れ，ほぼ CVD 法で製膜されている.

・TYPE III は $s p^{2}$ 成分が多くて水素が少なくかつ低硬度で あり，比較的グラファイトに近い DLC膜と言える。この TYPE IIIもほとんどは CVD 法で作製されている.

・TYPE IV は $s p^{2}$ 成分が多くて水素が多い低硬度の DLC 膜 である. CVD法, PVD法の両者を含んでもっとも市場で用 いられている膜であり, 磁気ディスク・湯水混合栓など耐摩 耗用途によく使われている.

・TYPE V はほとんど $s p^{3}$ 成分を含んでいない，グラッシー カーボン膜である.

・TYPE VI は有機ポリマーと見なせる膜である.

\section{5.むすび}

ダウンサイジングの進行により, 重要性を増した薄膜の評 価に放射光を利用した吸収端近傍 X 線吸収微細構造 (NEXAFS）の測定が用いられるようになった. NEXAFSの測定 は測定装置一放射光施設の数の少なさおよび放射線管理など の条件からの使い難さが問題であったが, 近年の軟 X 線放 射光施設の充実により, 以前に比べると格段に測定環境が整 ってきた. DLC 薄膜の構造指標としては最も重要な $s p^{2} / s p^{3}$ 成分比の測定手段としては他の手法の追随を許さない高精度 測定が可能であるため, DLC 薄膜の国際標準化プロジェク トでも標準評価手法として採用されている. 今後の薄膜評価 の標準として普及していくと考えられる.

\section{謝辞}

本解説記事の中で, DLC 膜国際標準化プロジェクトに関 しては DLC 研究会の長岡技術科学大学斎藤秀俊教授 · 東京 工業大学大竹尚登教授ほか多くの方々の努力と尽力の結果で す。厚く謝意を表します.

\section{[文献 $]$}

1) Development of Nanoimprint and Device Applications, ed. S. Matsui, (CMC Publishing Co., Ltd., Tokyo, 2011) [in Japanese].

2) Introduction to Synchrotron Radiation Research, ed. M. Watanabe and S. Sato, (Tohoku University Press, Sendai, 2004) [in Japanese].

3) T. Ohta: in Chemical Applications Of Synchrotron Radiation, ed. T. K. Sham (World Scientific Publishing Co., New Jersey, 2002).

4) A. Ando, S. Amano, S. Hashimoto, H. Kinosita, S. Miyamoto, T. Mochizuki, M. Niibe, Y. Shoji, M. Terasawa and T. Watanabe: Proc. IEEE Particle Accelerator Conf., Vancouver (1997) 757.

5) W. Jacob and W. Muller: Appl. Phys. Lett., 63 (1993) 1771.

6) A. C. Ferrari and J. Robertson: Phys. Rev. B, 61 (2000) 14095.

7) Report on "Standardization on Diamond-like Carbon Film and its Evolution Method", Project on Development of International Standard, METI (2011) [in Japanese].

8) M. Jaouen, G. Tourillon, J. Delafond, N. Junqua and G. Hug: Diamond Relat. Mater., 4 (1995) 200.

9) C. Lenardi, P. Piseri, V. Briois, C. E. Bottani, A. Li Bassi and P. Milani: J. Appl. Phys., 85 (1999) 7159.

10) A. Saikubo, N. Yamada, K. Kanda, S. Matsui, T. Suzuki, K. Niihara, H. Saitoh: Diamond Relat. Mater., 17 (2008) 1743.

11) Research Report on Dry Coating Market 2012 (Yano Research Institute Ltd., Tokyo) [in Japanese].

12) Hand book on DLC thin films, ed. H. Saitoh, (NTS Ink., Tokyo, 2006) [in Japanese]. 